\title{
ANALISIS PEMBELAJARAN TEMATIK PADA KURIKULUM 2013 DI SDN TANJUNGREJO 1 MALANG
}

\author{
1) Nury Yuniasih1, 2) Iskandar Ladamay, 3) Dyah Tri Wahyuningtyas \\ ${ }^{1}$ FKIP Universitas Kanjuruhan Malang \\ Jl. Soedanco Supriadi No. 48 Malang \\ Email: nury_yuniasih@yahoo.com
}

\begin{abstract}
This study aims to describe the implementation of thematic learning in SDN Tanjungrejo 1 Malang. The subjects were teachers and students of class I and IV SDN Tanjungrejo 1 Malang. The research approach used is qualitative research case study according to the research focus. Data collection techniques used in this study include: in-depth interviews, observation, and documentation. The results showed that the implementation of thematic learning in SDN Tanjungrejo 1 Malang is in accordance with the curriculum in 2013, but there are still some obstacles include: the ability of teachers to manage large classes and students who have not mastered basic skills. It can be concluded that the implementation of thematic learning class I and IV in SDN Tanjungrejo 1 Malang has been accomplished in accordance with the curriculum in 2013, but still requires the right strategy in order to be done well. Keywords: thematic learning, curriculum 2013.
\end{abstract}

ABSTRAK Penelitian ini bertujuan untuk mendeskripsikan pelaksanaan pembelajaran tematik di SDN Tanjungrejo 1 Malang. Subjek penelitian ini adalah guru dan siswa kelas I dan IV SDN Tanjungrejo 1 Malang. Pendekatan penelitian yang digunakan adalah penelitian kualitatif studi kasus sesuai dengan fokus penelitian. Teknik pengumpulan data yang digunakan dalam penelitian ini meliputi: wawancara mendalam, observasi, dan dokumentasi. Hasil penelitian menunjukkan bahwa pelaksanaan pembelajaran tematik di SDN Tanjungrejo 1 Malang sesuai dengan kurikulum tahun 2013, namun masih ada beberapa kendala antara lain: kemampuan guru untuk mengelola kelas besar dan siswa yang belum menguasai keterampilan dasar. Dengan demikian dapat disimpulkan bahwa penerapan tematik kelas belajar I dan IV di SDN Tanjungrejo 1 Malang telah dicapai sesuai dengan kurikulum tahun 2013, namun masih memerlukan strategi yang tepat agar dapat dilakukan dengan baik.

Kata kunci: pembelajaran tematik, kurikulum 2013.

PENDAHULUAN Penerapan kurikulum 2013 menuntut kesiapan guru dalam menghadapi perubahan pembelajaran. Kesiapan guru ini berkaitan erat dengan keberhasilan perubahan kurikulum terutama pada saat implementasinya di kelas. Oleh sebab itu, kemampuan guru dalam mempelajari pendekatan, strategi, model dan metode pembelajaran baru sangat dibutuhkan agar kompetensi siswa dapat tercapai. Selain kesiapan guru, kesiapan siswa menerima perubahan pembelajaran juga sangat penting dalam mencapai kompetensi. Sehingga, tugas utama guru yaitu untuk mendorong peserta didik mampu melakukan observasi, bertanya, bernalar dan mengkomunikasikan terhadap apa yang diperoleh dan diketahui selama proses pembelajaran. Hal ini dilakukan sebagai dasar penilaian keberhasilan suatu perubahan kurikulum.

Pelaksanaan kurikulum 2013 melalui pembelajaran tematik di tingkat sekolah dasar masih dilaksanakan pada kelas 1 dan 4 . Pembelajaran tematik untuk selanjutnya akan dilaksanakan pada semua kelas. Dalam proses pembelajaran tematik pada kurikulum 2013 perlu adanya catatan untuk mengamati apakah pelaksanaan sudah efektif. Tidak semua sekolah 
dasar yang sudah menerapkan pembelajaran tematik pada kurikulum 2013, hal ini disesuaikan dengan kondisi dari masing-masing sekolah dasar. Sedangkan di SDN Tanjungrejo 1 Malang merupakan salah satu sekolah dasar yang telah melaksanakan pembelajaran tematik.

Fokus dalam penelitian ini meliputi: (a) pelaksanaan pembelajaran tematik kurikulum 2013 di SDN Tanjungrejo 1 Malang. (b) kesiapan guru kelas 1 dan 4 dalam melaksanankan pembelajaran tematik. (c) tanggapan siswa kelas 1 dan 4 dalam menerima pembelajaran tematik kurikulum 2013. (d) kendala dalam melaksanakan pembelajaran tematik kurikulum.

Peraturan Menteri Pendidikan Dan Kebudayaan No. 67 Tahun 2013 menegaskan bahwa kurikulum 2013 untuk sekolah dasar didesain dengan menggunakan pembelajaran tematik terpadu. Pembelajaran tersebut dilaksanakan mulai dari kelas 1 sampai kelas 6 . Pembelajaran tematik terpadu ini perlu dilaksanakan karena: (a) Dalam kehidupan sehari-hari mata pelajaran berdiri sendiri-sendiri; (b) Tuntutan perkembangan ilmu pengetahuan dan teknologi (c) Keunggulan pembelajaran tematik materi yang disampaikan dikaitkan dengan kehidupan sehari-hari, dapat mengaitkan mata pelajaran satu dengan yang lain, dan pembelajaran aktif, efektif dan menyenangkan (Akbar, 2014).

Pembelajaran tematik adalah salah satu model pembelajaran yang menekankan pada pengorganisasian materi yang terintegrasi dan dipadukan pada suatu tema (Kurniawan, 2011). Menurut Akbar (2014) pembelajaran tematik merupakan pembelajaran yang melibatkan beberapa mata pelajaran untuk memberikan pengalaman yang bermakna kepada peserta didik. Pengembangan pembelajaran tematik merupakan pembelajaran yang dapat membantu siswa memahami konsep menjadi lebih mudah melalui tema yang disesuaikan dengan kehidupan sehari-hari.

Terdapat beberapa karakteristik yang perlu dipahami dari pembelajaran tematik menurut Hernawan (2011), yaitu: (1) Berpusat pada siswa (student centered), peran guru lebih banyak sebagai fasilitator yaitu memberikan kemudahan-kemudahan kepada siswa untuk melakukan aktivitas belajar. (2) Dapat memberikan pengalaman langsung kepada siswa (direct experiences), siswa dihadapkan pada sesuatu yang nyata (konkrit) sebagai dasar untuk memahami hal-hal yang lebih abstrak. (3) Pemisahan antar mata pelajaran menjadi tidak begitu jelas, fokus pembelajaran diarahkan kepada pembahasan tema-tema yang paling dekat berkaitan dengan kehidupan siswa. (4) Menyajikan konsep-konsep dari berbagai mata pelajaran dalam suatu proses pembelajaran, siswa dapat memahami konsep-konsep tersebut secara utuh. (5) Bersifat luwes (fleksibel), sebab guru dapat mengaitkan bahan ajar dari satu mata pelajaran dengan mata pelajaran yang lainnya. (6) Hasil pembelajaran dapat berkembang sesuai dengan minat dan kebutuhan siswa, siswa diberi kesempatan untuk mengoptimalkan potensi yang dimilikinya.

\section{METODE}

Sugiyono (2010:306) menyatakan peneliti kualitatif sebagai human instrumen, berfungsi menetapkan fokus penelitian, memilih informan sebagai sumber data, melakukan pengumpulan data, menilai kualitas data, analisis data, menafsirkan data dan membuat kesimpulan atas temuannya. Dalam penelitian kualitatif segala sesuatu yang akan dicari dari obyek penelitian belum jelas dan pasti masalahnya, sumber datanya, hasil yang diharapkan semuanya belum jelas. Rancangan penelitian masih bersifat sementara dan akan berkembang setelah peneliti memasuki obyek penelitian. Selain itu dalam memandang realitas, penelitian kualitatif berasumsi bahwa realitas itu bersifat holistik (menyeluruh), dinamis, tidak dapat dipisahpisahkan ke dalam variabel-variabel penelitian. Kalaupun dapat dipisah-pisahkan, variabelnya akan banyak sekali. Dengan demikian dalam penelitian kualitatif ini belum dapat dikembangkan instrumen penelitian sebelum masalah yang diteliti jelas sama sekali. Jadi peneliti adalah merupakan instrumen kunci dalam penelitian kualitatif.

Sugiyono (2010:298-299) menjelaskan bahwa penelitian kualitatif tidak menggunakan populasi, karena penelitian kualitatif berangkat dari kasus tertentu yang ada pada situasi sosial tertentu dan hasil kajiannya tidak akan diberlakukan ke populasi, tetapi ditransferkan ke tempat lain pada situasi sosial yang memiliki kesamaan dengan situasi sosial pada kasus yang 
dipelajari. Sampel dalam penelitian kualitatif bukan dinamakan responden, tetapi sebagai nara sumber, atau partisipan, informan, teman dan guru dalam penelitian. Sampel dalam penelitian kualitatif, juga bukan disebut sampel statistik, tetapi sampel teoritis, karena tujuan penelitian kualitatif adalah untuk monghasilkan teori. Pada penelitian kualitatif, peneliti memasuki situasi sosial yang dapat berupa lembaga pendidikan tertentu, melakukan observasi dan wawancara kepada orang-orang yang dipandang tahu tentang situasi sosial tersebut. Sumber data dalam penelitian ini adalah kepala sekolah, guru dan siswa SDN Tanjungrejo 1 Malang. Dalam pelaksanaan pembelajaran tematik pada kurikulum 2013 diterapkan di kelas 1 dan 4 . Sampel pada penelitian ini guru dan siswa kelas 1 dan kelas 4 SDN Tanjungrejo 1 Malang.

Dalam penelitian ini pengumpulan data dilakukan dengan (1) observasi partisipasif, Partisipasi aktif dipilih menjadi jenis observasi partisipasif dalam penelitian ini. Partisipasi aktif yakni dalam observasi ini peneliti ikut melakukan apa yang dilakukan nara sumber, tetapi tidak sepenuhnya lengkap. Peneliti dalam mengumpulkan data ikut observasi partisipasif dalam beberapa kegiatan, tetapi tidak semuanya. (2) wawancara mendalam, merupakan percakapan untuk menggali informasi sebanyakbanyaknya dari informan yang bertujuan untuk memperoleh konstruksi yang terjadi tentang orang, kejadian, aktivitas organisasi, perasaan, motivasi dan pengetahuan seseorang tentang pengalamannya,dan (3) dokumentasi, studi dokumentasi pada penelitian ini sebagai pelengkap dari observasi dan wawancara agar data lebih kredibel dan sebagai bukti pelaporan bahwa penelitian ini benar-benar dilaksanakan.

Langkah-langkah yang dilakukan selama proses analisis data pada penelitian ini adalah sebagai berikut: (1) Reduksi Data (Data Reduction), Kehadiran peneliti dalam lokasi penelitian yang lama dan proses pengambilan data melalui beberapa teknik mengakibatkan data yang diperoleh semakin banyak dan rumit. Untuk itu diperlukan reduksi data agar bisa memilah dan memilih data yang diperlukan atau relevan dengan fokus penelitian yang telah ditentukan. (2) Penyajian Data (Data Display), Sugiyono (2010:341) bahwa yang paling sering digunakan untuk menyajikan data dalam penelitian kualitatif adalah dengan teks yang bersifat naratif. (3) Verifikasi (Conclusion Drawing), penarikan verifikasi dan penarikan kesimpulan. Data-data yang telah diperoleh peneliti dari observasi, wawancara dan dokumentasi secara tidak langsung peneliti sudah menemukan kesimpulan untuk fokus penelitian yang telah ditentukan. Kesimpulan sementara yang telah ditemukan oleh peneliti akan diverifikasi dengan mencari bukti-bukti yang lebih valid dan konsisten sehingga kesimpulan tersebut merupakan kesimpulan yang kredibel.

\section{HASIL DAN PEMBAHASAN}

Pembelajaran tematik pada kurikulum 2013 di kelas 1 dan 4 di SDN Tanjungrejo 1 pelaksanaannya disesuaikan dengan buku pegangan guru dan buku siswa. Dalam pelaksanaannya selain menggunakan buku guru dan buku siswa, guru kelas 4 menggunakan lembar kegiatan siswa untuk menunjang materi dan evaluasi yang ada pada buku guru dan buku siswa. Selain mengacu pada buku guru dan buku siswa di dalam proses pembelajarannya metode yang digunakan guru dalam pembelajaran tematik di kelas 1 dan 4 mengacu pada pembelajaran yang aktif, kreatif dan menyenangkan. Untuk metode pembelajaran seperti belajar secara berkelompok digunakan pada kelas 4 karena di kelas 1 siswa masih dalam tahap awal pengenalan sehingga jika belajar berkelompok masih belum bisa fokus ke materi pembelajaran dan ramai sendiri. Sedangakan untuk siswa kelas 4 dapat menggunakan metode belajar secara berkelompok karena mereka sudah dapat fokus dalam pembelajaran walaupun kadang masih ramai dan sulit diatur. Media pembelajaran juga sering digunakan oleh guru kelas 1 dan 4 untuk menunjang dalam menyampaikan materi, terutama guru kelas 4 yang mampu mengunakan IT dalam media pembelajaran. Menurut kepala sekolah dan guru pendekatan metode dan media dalam pelaksanaan pembelajaran tematik di kelas 1 dan 4 disesuaikan dengan materi dan kegiatan.

Pelaksanaan pembelajaran tematik di SDN Tanjungrejo 1 Malang bepusat pada siswa sehingga membutuhkan kesiapan dari siswa. Guru dapat mengkondisikan pembelajaran di kelas dengan pembelajaran yang menyenangkan, 
sehingga siswa dapat belajar dengan senang, nyaman dan dapat memahami materi yang disampaikan. Dalam proses pembelajaran tematik di kelas 1 masih ada kesulitan karena beberapa belum menguasai keterampilan dasar: membaca, menulis, dan berhitung, sedangkan pada kelas 4 dengan jumlah siswa yang terlalu banyak yaitu 48 siswa membuat proses pembelajaran juga terhambat karena harus ada pengelolaan kelas yang tepat. Siswa dibimbing untuk belajar mengamati objek sesuai dengan kegiatan, mencoba untuk melakukan percobaan dan mengikuti instruksi guru dan mengkomunikasikan hasil pengamatannya di depan kelas. Berdasarkan hasil wawancara dengan guru dan beberapa siswa, terlihat siswa lebih senang dengan pembelajaran tematik daripada pembelajaran KTSP karena beban belajar yang ringan. Tetapi dalam pelaksanaan di kelas memang ada beberapa siswa yang masih bingung dengan pembelajaran tematik ini.

Evaluasi pembelajaran tematik di kelas 1 dan 4 meliputi proses (sikap dalam belajar, tugas, dll) dan hasil (ulangan harian, UTS dan UAS). Evaluasi proses karena tidak ada rubrik penilaian khusus maka kreatifitas guru yang menentukan. Persiapan evaluasi hasil UTS dan UAS guru harus menekankan pada muatanmuatan mata pelajaran karena soal ujian dari pusat berupa muatan-muatan mata pelajaran seperti muatan Matematika, IPA, IPS, dll. Penilaian pembelajaran tematik di kelas 1 dan 4 meliputi: penilaian pengetahuan, sikap, dan keterampilan. Penilaian siswa lebih banyak dilakukan pada proses pembelajaran, setiap hari harus ada penilaian proses. Penilaian tersebut dipaparkan dalam bentuk deskripsi yang dituliskan pada rapor hasil belajar siswa. Kendala dalam penulisan rapor, guru harus menuliskan kompetensi yang dikuasai siswa dan yang masih membutuhkan bimbingan guru. Penulisan rapor secara deskripsi memang memberatkan tugas guru dan memerlukan waktu lama dalam pengerjaaanya, sehingga jadwal pembegian rapor sering mundur dari yang ditetapkan.

Pendapat dari wali murid, pembelajaran kurikulum 2013 ini sulit dipahami oleh mereka. Pada saat ingin mengajari anak-anak mereka, mereka bingung apa yang harus diajarkan. Terlebih lagi wali murid merasa pembelajaran tematik terlalu santai belajarnya karena tidak banyak tugas yang diberikan kepada siswa. Sehingga anak-anaknya lebih banyak bermain daripada belajar. Kedalaman materi juga menjadi pertimbangan, bagi wali murid kelas 1 merasa perkembangan ketrampilan dasar anaknya terlalu lambat. Bagi wali murid kelas 4 merasa materi yang diajarkan terlalu sempit kurang ada pendalaman.

Pelaksanaan pembelajaran tematik pada kurikulum 2013 dalam pelaksanaannya tidak dapat sepenuhnya sempurna, karena pembelajaran tematik menyesuaikan dengan karakteristik siswa dan kondisi di lapangan. Berdasarkan hasil observasi dan wawancara di SDN Tanjungrejo 1 Malang kendala yang ditemukan dalam pelaksanaan pembelajaran tematik pada kurikulum 2013 meliputi: (1) Buku guru dan buku siswa yang disediakan pendalaman materinya masih kurang sehingga guru masih perlu mengembangkan dan memperdalam lagi. (2) Dalam pelaksanaan pembelajaran tematik ada beberapa guru masih kurang mengembangkan pendekatan, metode dan media pembelajaran, karena masih terbiasa dengan pembelajaran lama. (3) Penulisan rapor secara deskripsi selain membuat tugas guru semakin berat juga membuat wali murid merasa tidak puas, karena hasil berlajar siswa tidak dalam bentuk nilai. (4) Pembelajaran tematik pada kurikulum 2013 tidak dapat dilaksanakan di kelas yang gemuk, karena terkait dengan pengelolaan kelas.

\section{SIMPULAN}

Berdasarkan hasil penelitian dan pembahasan mengenai pelaksanaan pembelajaran tematik pada kurikulum 2013 di SDN Tanjunrejo 1 Malang, maka dapat disimpulkan bahwa: (1) Pelaksanaan pembelajaran tematik pada kurikulum 2013 SDN Tanjungrejo 1 Malang yang telah dilaksanakan sesuai dengan kompetensi pada kurikulum 2013, serta sudah sesuai dengan beberapa karakteristik dalam pembelajaran tematik yang meliputi berpusat pada siswa (student centered), dapat memberikan pengalaman langsung kepada siswa (direct experiences), (2) Persiapan guru kelas 1 dan 4 dalam pembelajaran tematik di SDN Tanjungrejo 1 Malang telah sesuai dengan tahapan pembelajaran tematik pada kurikulum 2013 yaitu 
perencanaan, pelaksanaan dan evaluasi sudah mencerminkan pembelajaran tematik. Kendala dalam pelaksanaan pembelajaran tematik di SDN Tanjungrejo 1 Malang meliputi, pembelajaran tematik di kelas 1 masih ada kesulitan karena beberapa belum menguasai keterampilan dasar: membaca, menulis, dan berhitung, sedangkan pada kelas 4 dengan jumlah siswa yang terlalu banyak yaitu 48 siswa membuat proses pembelajaran juga terhambat karena harus ada pengelolaan kelas yang tepat.

\section{REFERENSI}

Akbar, Sa'dun. (2014). Penyegaran Pembelajaran Tematik Berbasis KKNI Kurikulum 2013: makalah kuliah umum. Malang: Universitas Kanjuruhan Malang.

Hermawan, Asep Herry. (2011). Pengembangan Model Pembelajaran Tematik di Kelas Awal Sekolah Dasar. Bandung: Modul Jurusan Kurikulum dan Teknologi Pendidikan FIP UPI.

Kurniawan, Deni. (2011). Pembelajaran Terpadu. Bandung: Pustaka Cendikia Utama.

Peraturan Menteri Pendidikan Dan Kebudayaan No. 67 Tahun 2013.

Sugiyono. (2010). Metode Penelitian Pendidikan Pendekatan Kuantitatif, Kualitatif, dan REG. Bandung: Alfabeta. 